\title{
Evaluation of a Multiplex PCR Assay for Rapid Diagnosis of Fowl Typhoid
}

\author{
Susmita Pal, Samir Dey*, Kunal Batabyal, Abhiroop Banerjee, \\ Siddhartha Narayan Joardar and Devi Prasad Isore
}

\author{
Department of Veterinary Microbiology, West Bengal University of Animal and Fishery \\ Sciences (WBUAFS), Belgachia, Kolkata-700037, India
}

*Corresponding author

\section{A B S T R A C T}

\section{Keywords}

Fowl typhoid, $g \lg C$, Multiplex, Poultry, PCR, Salmonella gallinarum, speC

Article Info

Accepted:

15 May 2019

Available Online:

10 June 2019
Despite Fowl typhoid (FT) eradication in commercial poultry of some parts of the world, outbreak threats are not eliminated in poultry of developing countries. In the current study, we reported molecular identification of Salmonella gallinarum in Indian isolates from backyard poultry by a multiplex PCR assay. Boiled culture lysates of Salmonella Gallinarum isolates $(n=2)$ from an outbreak showed positive amplifications of $g \lg C$ and speC genes in duplex PCR with $174 \mathrm{bp}$ and $252 \mathrm{bp}$ products, respectively. In multiplex $\mathrm{PCR}$ assay, primers for salmonella plasmid virulence gene $(s p v \mathrm{C})$ were also added in same reaction mixture. No amplifications were noticed in negative controls with other Salmonella serotypes and non -Salmonella organisms. This multiplex PCR assay was found to be rapid and specific in diagnosis of fowl typhoid.

\section{Introduction}

Two biovars of Salmonella enterica subsp. enterica biovar Gallinarum and Pullorum, causing fowl typhoid (FT) and pullorum disease of poultry, respectively are economically important in poultry industry. Eradication in commercial poultry in some parts of the world was achieved through improved surveillance and culling. However, threats of FT outbreaks are not eliminated in commercial and backyard poultry of developing countries (Barrow and Freitas Neto, 2011). Accurate diagnosis of the pathogen is pre- requisite for effective adaptation of control measures. Flock history, mortality, clinical signs and post mortem lesions are suggestive of FT infection but isolation and biochemical identification of the organism still remain 'gold standard' method of confirmation (OIE, 2018). The conventional methods of biochemical identification are laborious, and time consuming. $\mathrm{O}-$ and $\mathrm{H}$-antigen specific antisera are used commonly for slide and tube agglutination tests to identify Salmonella serovars. Therefore, rapid detection technique of the major Salmonella serovars is utmost necessary. DNA based identification of Salmonella serovars Gallinarum and Pullorum 
was primary interest by many researchers in last few years. Several genes for PCR target in the detection of the serovar Gallinarum were used. Polymorphic areas of $g \operatorname{lgC}$ and speC genes (Kang et al., 2011), flagellar biosynthesis gene $f l h B$ (Xiong et al., 2016), fimbrial operon gene $b c f D$ (Zhuang et al., 2014, fimbrial operon gene sefA (Gong et al., 2016), flagellar biosynthesis gene $f l h B$ (Xiong et al., 2017), SPUL 2693(Xu et al., 2018) were amplified successfully.

Besides, Salmonella plasmid virulence $(s p v C)$ gene is present in the plasmid of seven serovars of Salmonella including the most frequent etiologic agents $S$. gallinarumpullorum, S. typhimurium and S. enteritidis (Chiu and $\mathrm{Ou}, 1996)$. The $s p v$ region contains three genes required for the virulence phenotype in mice (Guiney and Fierer, 2011).

In the current study, molecular identification and characterisation was carried out by simultaneous PCR amplification of $g l g \mathrm{C}$, speC and spvC genes with Salmonella gallinarum strains from an outbreak of FT in backyard poultry in West Bengal, India.

\section{Materials and Methods}

\section{Bacterial strains}

Two isolates of Salmonella gallinarum (WBSG-1, WBSG-2) obtained from the Department of Veterinary Microbiology, West Bengal University of Animal and Fishery Sciences, Kolkata, India from an outbreak of FT in Vanaraja fowl were used.

The isolates were conventionally serotyped (antigenic structure 9, 12:-:-) with antisera at National Salmonella and Escherichia Centre, Kasauli, India. Salmonella typhimurium ATCC 13076 and clinical isolates of E. coli, Pseudomonas aeruginosa were used for negative control in the present study.

\section{Preparation of culture lysate}

Bacterial culture lysate was prepared as described previously (Pal et al., 2017). One $\mathrm{ml}$ of overnight broth cultures of bacterial growth was taken in $1.5 \mathrm{ml}$ microcentrifuge tube (Tarsons, India) and centrifuged at 6000 rpm for $5 \mathrm{~min}$. The pellet was washed twice with Tris-ethylenediaminetetra acetic acid (EDTA) buffer and was re-suspended in $1 \mathrm{ml}$ Tris-EDTA buffer. Then, the suspension was boiled for 10 min followed by chilling in ice. Then, the supernatant was collected as template DNA after cell debris was removed by centrifugation at $6000 \mathrm{rpm}$ for $5 \mathrm{~min}$ and stored at $-20^{\circ} \mathrm{C}$.

\section{PCR assay}

PCR assay was performed by multiplex-PCR targeting $g \lg C$ and $s p e C$ genes in a single reaction mixture as described previously (Kang et al., 2011) with little modifications. The amplification reaction was carried out in a $50 \mu \mathrm{l}$ PCR mixture containing $10 \mu \mathrm{l}$ of $5 \mathrm{x}$ PCR buffer, $1.5 \mathrm{mM} \mathrm{MgCl} 2,200 \mu \mathrm{M}$ dNTPs, $0.6 \mu \mathrm{M}$ each $g \lg C$ forward and reverse primers, $0.4 \mu \mathrm{M}$ each speC forward and reverse primers respectively, $1.5 \mathrm{U}$ GoTaq Flexi DNA Polymerase (Promega, USA), $5 \mu \mathrm{l}$ culture lysate DNA and nuclease- free water up to $50 \mu \mathrm{l}$. The PCR was carried out in a thermocycler (Eppendorf, Germany) using the following cycle: initial denaturation of 5 minutes at $94{ }^{\circ} \mathrm{C}$ followed by 30 cycles of denaturation each at $94{ }^{\circ} \mathrm{C}$ for 30 seconds, annealing at $60{ }^{\circ} \mathrm{C}$ for 30 seconds, extension at $72{ }^{\circ} \mathrm{C}$ for 30 seconds and final extension at $72{ }^{\circ} \mathrm{C}$ for 7 minutes. In triplex PCR assay, primers for Salmonella plasmid virulence gene $(s p v C)$ were also added for detection of virulence plasmid (Table 1).

The electrophoresis was carried out using $2 \%$ agarose gel with $0.5 \mu \mathrm{l} / \mathrm{ml}$ ethidium bromide in $1 \mathrm{x}$ TBE buffer at $8 \mathrm{~V} / \mathrm{cm}$ for $1 \mathrm{~h}$. The 
amplicons were observed under UV transilluminator (UVP, UK) and photographed.

\section{Results and Discussion}

Two boiled cuture lysates of Salmonella gallinarum isolates (WBSG1, WBSG2) showed positive amplification of $174 \mathrm{bp}$ and 252 bp in multiplex PCR targeting $g \lg C$ and speC genes, respectively (Figure 1). No amplification was observed in negative controls including Salmonella typhimurium ATCC 14028. An additional product of $s p v \mathrm{C}$ gene (571 bp) was observed in triplex PCR assay.

Although several PCR assays have been developed for molecular detection of Salmonella gallinarum, conventional isolation and biochemical identification of culture is still used as "gold standard". Few PCR techniques were not widely used as they have inherent limitations like requiring additional steps with restriction enzyme digestion (Kwon et al., 2000), semi-nested PCR (Pugliese et al., 2011), or another allele PCR (Shah et al., 2005). However, the primers developed by Kang et al., (2011) correctly identified SG in culture lysates without extraction of pure genomic DNA indicating its usefulness in any diagnostic laboratory and greatly shorten the time of serotype identification. Like our study, Mamnan et al., (2014) also revalidated this duplex PCR assay for investigating outbreaks of fowl typhoid caused by Salmonella gallinarum in Kaduna State, Nigeria. This duplex PCR have been reported to differentiate between biovars Gallinarum and Pullorum targeting $g \lg C$ and speC genes. Biovar Pullorum does not yield amplicon from speC gene using the primers but biovar Gallinarum yields the products of both speC and $g \lg C$ genes using these primers (Kang et al., 2011). The spv region in virulence plasmid is associated with systemic spread of the pathogen (Heithoff et al., 2008).

Triplex PCR assay in the current study, in addition detects virulence plasmid in the bacterium simultaneously. Xiong et al., (2018) reported another multiplex PCR method focused on three specific genes, stn, I137_08605 and ratA recently. Based on bioinformatics analysis, they found that gene I137_08605 was present only in Salmonella pullorum and Salmonella gallinarum, and region of difference in ratA gene was deleted only in $S$. Pullorum after comparison with that of Salmonella gallinarum and other Salmonella serovars.

Table.1 Oligonucleotides (primers) used for multiplex PCR and serovar identification of Salmonella gallinarum

\begin{tabular}{|c|c|c|c|c|}
\hline Genes & Primer & Oligonucleotides (5' -3') & $\begin{array}{l}\text { Amplification } \\
\text { product (bp) }\end{array}$ & References \\
\hline $\begin{array}{l}\text { glgC } \\
\text { speC }\end{array}$ & $\begin{array}{l}\text { SG-L } \\
\text { SG-R } \\
\text { SGP-L } \\
\text { SGP-R }\end{array}$ & $\begin{array}{l}\text { GAT CTG CTG CCA GCT CAA } \\
\text { GCG CCC TTT TCA AAA CAT A } \\
\text { CGG TGT ACT GCC CGC TAT } \\
\text { CTG GGC ATT GAC GCA AA }\end{array}$ & $\begin{array}{l}174 \\
252\end{array}$ & $\begin{array}{l}\text { Kang et al., } \\
2011\end{array}$ \\
\hline $\operatorname{spv} \mathrm{C}$ & $\begin{array}{l}\text { SPV-1 } \\
\text { SPV-2 }\end{array}$ & $\begin{array}{l}\text { ACTCCTTGCACAACCAAATGCGGA } \\
\text { TGTCTTCTGCATTTCGCCACCATCA }\end{array}$ & 571 & $\begin{array}{l}\text { Chiu and } \\
\text { Ou(1996) }\end{array}$ \\
\hline
\end{tabular}


Fig.1 Multiplex PCR assays for identification of Salmonella gallinarum

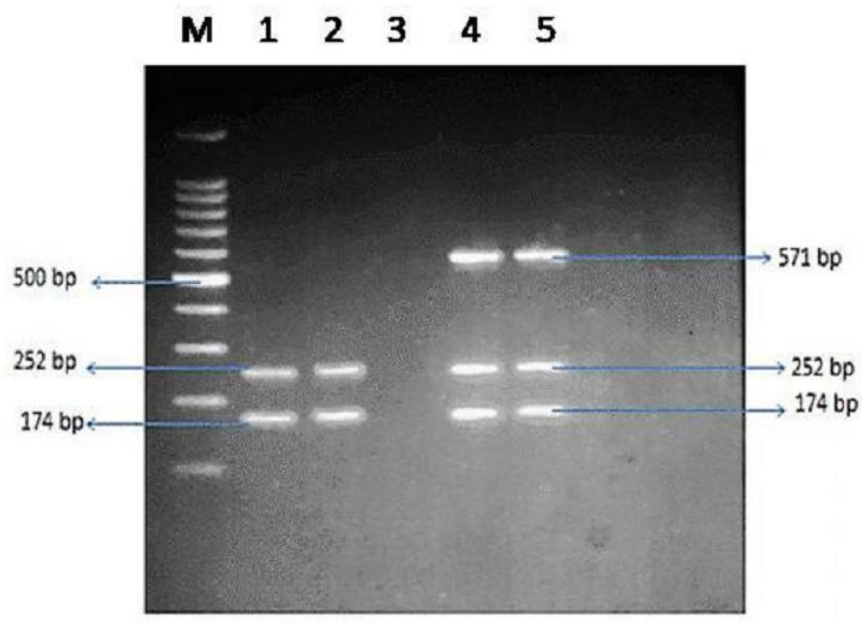

\section{Figure 1: Multiplex PCR assays for identification of of Salmonella Gallinarum}

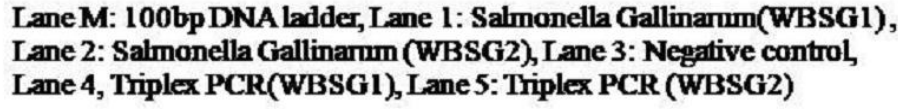

Triplex PCR based molecular identification has the potential to provide precision in the methods of rapid diagnosis of fowl typhoid in poultry in areas where the disease is enzootic like in India.

\section{Acknowledgments}

The authors are grateful to the ViceChancellor, Director of Research, West Bengal University of Animal and Fishery Sciences and Dean, Faculty of Veterinary Science for providing necessary facilities. Thanks are due to Indian Council of Agricultural Research (ICAR), New Delhi for financial assistance (Development Grant 7.1).

\section{References}

Barrow P.A. and Freitas Neto O.C. 2011. Pullorum disease and fowl typhoid-new thoughts on old diseases: a review. Avian Path., 40: 1-13
Chiu, C. H., and Ou, J. T. 1996. Rapid identification of Salmonella serovars in feces by specific detection of virulence genes, invA and $s p v C$, by an enrichment broth culture-multiplex PCR combination assay. J. Clin. Microbiol., 34(10): 26192622.

Gong J, Zhuang L, Zhu C, Shi S, Zhang D, Zhang L, Yu Y, Dou X, Xu B, Wang C.2016. Loop-mediated isothermal amplification of the sefA gene for rapid detection of Salmonella enteritidis and Salmonella gallinarum in chickens. Foodborne Pathog Dis., 13(4):177-81

Guiney D.G. and Fierer J.2011. The Role of the spv-Genes in Salmonella pathogenesis. Front. Microbiol., v. 2, p. 129.

Heithoff, D.M., Shimp, W.R., Lau, P.W., Badie, G., Enioutina, E.Y., Daynes, R.A., Byrne, B.A., House, J.K. and Mahan, M.J. 2008. Human Salmonella clinical isolates distinct from those of animal origin. Appl. Environ. Microbiol., 10: 1757-1766.

Kang, M.S., Kwon, Y.K., Jung, B.Y., Kim, A., 
Lee, K.M., An, B.K., Song, E.A., Kwon, J.H., Chung, G.S. 2011. Differential identification of Salmonella enterica subsp. enterica serovar Gallinarum biovars Gallinarum and Pullorum based on polymorphic regions of $\mathrm{glgC}$ and $\mathrm{speC}$ genes. Vet. Microbiol. 147: 181-185.

Kwon, H.J., Park, K.Y., Yoo, H.S., Park, J.Y., Park, Y.H., Kim, S.J. 2000. Differentiation of Salmonella enterica serotype Gallinarum biotype Pullorum from biotype Gallinarum by analysis of phase 1 flagellin $\mathrm{C}$ gene $(f l i C)$. $\mathrm{J}$. Microbiol. Methods 40: 33-38.

Mamman P.H, Kazeem H.M, Raji M.A., Nok A.J, Kwaga J.K.P. 2014. Isolation and Characterization of Salmonella gallinarum from outbreaks of fowl typhoid in Kaduna State, Nigeria. Int. J. Public Hlth. Epidemiol. 3(10):82-88

OIE (2018). Fowl typhoid and Pullorum disease. OIE terrestrial manual, Chap. 2.3.1. $\mathrm{p}: 1-17$

Pal S, Dey S, Batabyal K, Banerjee A, Joardar SN, Samanta I, Isore DP. 2017. Characterization of Salmonella Gallinar isolates from backyard poultry by polymerase chain reaction detection of invasion (invA) and Salmonella plasmid virulence $(s p v \mathrm{C})$ genes, Veterinary World, 10(7): 814-817

Pugliese N., Circella E., Pazzani C., Pupillo A., Camarda A. 2011.Validation of a seminested PCR approach for rapid detection of Salmonella enterica subsp. enterica serovar Gallinarum. J. Microbiol. Methods 85: 22-27

Shah, D.H., Park, J.H., Cho, M.R., Kim, M.C., Chae, J.S., 2005. Allele-specific PCR method based on $r f b S$ sequence for distinguishing Salmonella gallinarum from Salmonella pullorum: serotypespecific $r f b S$ sequence polymorphism. J. Microbiol. Methods 60, 169-177.

Xiong D, Song L, Pan Z and Jiao X.2018. Identification and discrimination of Salmonella enterica serovar Gallinarum biovars Pullorum and Gallinarum based on a one-step multiplex PCR assay. Front. Microbiol. 9: 1718.

Xiong D, Song L, Tao J, Zheng H, Zhou Z, Geng S, Pan Z, Jiao X.2017. An Efficient multiplex PCR-based assay as a novel tool for accurate inter-serovar discrimination of Salmonella enteritidis, $S$. pullorum/gallinarum and $S$. Dublin. Front Microbiol. 16(8): 420.

Xiong, D., L. Song, S. Geng, J. Tao, S. An, Z. Pan, and X. Jiao. 2016. One-step PCR detection of Salmonella pullorum/Gallinarum using a novel target: the flagellar biosynthesis gene flhB. Front. Microbiol. 7:1863

$\mathrm{Xu}$ Y., Hu Y., Guo Y., Zhou Z., Xiong D., Meng C., Li Q., Geng S., Pan Z., and Jiao X. 2018. A new PCR assay based on the new gene-SPUL 2693 for rapid detection of Salmonella enterica subsp. enterica serovar Gallinarum biovars Gallinarum and Pullorum. Poultry Sci., 97: 40004007.

Zhuang L, Gong J, Li Q, Zhu C, Yu Y, Dou X, Liu X, Xu B, Wang C.2014. Detection of Salmonella spp. by a loop-mediated isothermal amplification (LAMP) method targeting $b c f D$ gene. Lett Appl Microbiol., 59(6): 658-64.

\section{How to cite this article:}

Susmita Pal, Samir Dey, Kunal Batabyal, Abhiroop Banerjee, Siddhartha Narayan Joardar and Devi Prasad Isore. 2019. Evaluation of a Multiplex PCR Assay for Rapid Diagnosis of Fowl Typhoid. Int.J.Curr.Microbiol.App.Sci. 8(06): 2054-2058. doi: https://doi.org/10.20546/ijcmas.2019.806.245 